\title{
Research Activities on LCA and LCM in Poland
}

\author{
Zenon Foltynowicz and Zbigniew Stanisław Kłos
}

\begin{abstract}
The main goal of this paper is to present the history and actual situation in research on LCA and LCM in Poland. This task will be performed by reviewing the different activities and their results in this field, from the very beginning. The paper includes the review of the activities of LCA/LCM main research centres in Poznań (Poznań University of Technology (PUT), Poznań University of Economics and Business (PUEB)), Cracow (Polish Academy of Sciences, AGH University of Science and Technology, Cracow University of Economics), Zielona Góra (University of Zielona Góra), Bydgoszcz (UTP University of Science and Technology), Katowice-Gliwice (Silesian University of Technology), Częstochowa (Częstochowa University of Technology) and Szczecin (ZUT Western Pomeranian University of Technology). LCA/LCM researches are also performed in several smaller research groups in R\&D centres. In the end of the paper, some conclusions referring to the actual situation of research on LCA/LCM, dealing with critical evaluation of the LCA/LCM centres in Poland location, issues and problems addressed, areas of the projects covered and the desired activities in the future, are presented.
\end{abstract}

\section{Introduction}

Environmental life cycle assessment has developed fast over the last three decades. A comprehensive review of the historical development of LCA has recently been presented by Guinée [22]. So far, a description and summary of the state of research on LCA in Poland has been made several times, for the first time in 1990 [24]. The first studies worldwide, which are currently considered as LCA, were carried out in the late 1960s and early 1970s. In the years 1970-1990, the LCA concept was

\footnotetext{
Z. Foltynowicz $(\bowtie)$

Poznań University of Economics and Business, Poznań, Poland

e-mail: zenon.foltynowicz@ue.poznan.pl
}

\section{Z. S. Kłos}

Faculty of Civil and Transport Engineering, Poznań University of Technology, Poznań,

Poland 
developed with widely divergent approaches and terminologies. The 1990s brought about a remarkable increase in research activities around the world, reflecting, inter alia, the number of published LCA guides and textbooks. In 1990-2000, harmonization of methods took place, thanks to SETAC coordination and ISO standardization activities, providing a standardized framework and terminology as well as platforms for debate and harmonization of LCA methods. In addition, the first scientific journals appeared with LCA as their main subject.

\section{Early Works in Poland}

As a starting point, the first attempts of introduction of LCA/LCM aspects into research practice in Poland are presented. These "pre-historical" activities were connected with the implementation of life cycle frames into analysis of environmental impacts of technical objects, as it was presented in a paper focused on consideration on the usefulness of determination of environmental impacts of the machine and device existence in the life cycle [23], published in Scientific Works of PUT, series: Machines and Vehicles, in 1986 (author: Zbigniew Kłos). Among other activities, the first book on LCA-related issues by Zbigniew Kłos entitled "Environment Protection Oriented Property of Technical Objects. A Study of Valuation of Machines and Devices Influence on Environment", published by Editions of PUT in 1990 [3], and the first PhD thesis "Ecobalancing of Machines and Devices with the Example of Air Compressors", defended by Grzegorz Laskowski at Faculty of Machines and Vehicles, PUT, in 1999 (supervisor: Zbigniew Kłos), should be pointed out. Then there were in the 1990s other activities accomplished, like engagement in work activities of European LCA research groups: SETAC-Europe Workgroup on LCA and Conceptually Related Programs and SETAC-Europe Workgroup on LCA Case Studies and participation in the European Union Research Programme LCANET as well as in thhe European Union Concerted Action CHAINET (Zbigniew Kłos). More about these works were presented in publication of Kłos [25] and Adamczyk [1] working at the University of Economics in Cracow. Since then, there have been more and more publications on the subject. In addition to these two centres, which initiated the LCA research in Poland, this topic began to develop in the following scientific centres: PUEB, University of Zielona Góra, Gdynia Maritime Academy, Mineral and Energy Economy Research Institute of Polish Academy of Sciences, Central Mining Institute and Wood Technology Institute. The innovative scope of LCA research in these centres has been discussed in a number of scientific reports, among others in the review papers of Kłos [16, 25, 26, 65], Lewandowska [15, 16, 32, 39, 65] and Kulczycka [32].

This review paper characterizes individual centres, scientists working in them and the main research topics. Our goal is not to re-describe them; however short characteristics will be presented in the research part when discussing the results of the bibliometric ranking. The growing number of publications in both national and significant international journals was also pointed out in these studies. The list of 
publications of Polish researchers in the journals possessing impact factor already includes several dozen items. The first publication in a leading journal, IJLCA, with Kłos co-authorship appeared in 2000 [57] and subsequent completely by national authors in 2004 [40, 43]. The following years brought further publications together with the growing number of centres starting research in the field of LCA/LCM. These publications meet a growing interest as evidenced by their increasing number of citations. However, no comparative analysis of these publications has yet been carried out. The aim of this work is therefore not only the presentation of scientists from a given Polish LCA centres but also an attempt of the bibliometric analysis of Polish LCA's scientist performance. The question arises: what kind of indicators would be really useful for such analysis? Under evaluation of a paper, the three main factors, impact factor of a journal, number of citations and year of publication, seem to determine the importance of a given publication.

\section{Proposed Bibliometric Method of Polish LCA's Scientist Achievement Evaluation}

\subsection{Methodology}

The number of scientific publications and the number of journals have increased considerably in the last few years. How to find out in this thicket which are valuable and which are not worth? Some probably remember that there is Eugene Garfield who began a new era in the processes of evaluation and measurement of scientific publications with his radical invention, the Science Citation Index (SCI), which enabled the statistical analysis of large-scale scientific literature [19]. Then, several methodologies for evaluating scientific papers were proposed [54]. Early work in this field, consisting in determining the quality of the best works, as mentioned in [54], approached the qualitative dimension of the work represented by the journal's impact factor and the number of citations of the analysed works.

The quality of work should be assessed through its impact on the scientific community. With this in mind, we used the Methodi Ordinatio [54], a method in order to rank publications of Polish LCA researchers.

\subsection{Methodi Ordinatio Description}

Methodi Ordinatio is a multi-criteria assessment model (InOrdinatio) used to rank publications according to a set of criteria such as journal impact factor in which the paper was published, year of publication and number of citations [54]. The equation InOrdinatio (1) is applied to identify the scientific works' ranking: 
InOrdinatio $=(\mathrm{IF} / 1000)+$ alfa $*[10-($ ResearchYear - PublishYear $)]+\mathrm{Ci}$

Where:

- IF is the journal impact factor in which the paper was published.

- alfa is the weighting factor ranging from 1 to 10 , to be attributed by the researcher.

- ResearchYear is the year in which the research was developed.

- PublishYear is the year in which the paper was published.

- $\mathrm{Ci}$ is the number of times the paper has been cited in the literature.

The authors of the method [54] adopted the following assumptions for the equation InOrdinatio:

(a) Originally, the impact factor IF is divided by 1000 (thousand), striving to normalize its value in relation to the other criteria. We do not agree with this assumption because it depreciates this important indicator. That is why in our calculations it was assumed that we will multiply IF by 10 to give it the right rank. It is not easy to publish an article in a journal characterized by a relatively large IF. The use of the journal impact factor in academic review, promotion and tenure evaluations has been very recently discussed by McKiernan et al. [50].

(b) The equation contains a weighting factor "alfa", the value of which the researcher assigns. It can be from 1 to 10 . If its value is close to 1 , it means that the researcher assigns less importance to the year of publication as a criterion, and the closer to 10 , when he assigns the greater importance of this criterion.

\subsection{Methodi Ordinatio Application for Analysis of Polish Authors LCA's Publications}

\subsubsection{Adopted Research Assumptions}

The scope of the research included publications in the field of LCA by Polish specialists. Their list was established on the basis of research in the scientific community. To calculate the InOrdinatio indicator, it was decided to use publications from the period 1995-2019. In the study, year 2010 was adopted as the current turning point. For years below 2010, the value of "alpha" as 5 was arbitrarily assumed. For the present decade, the value of "alpha" was assumed to be 10 , because a shorter time elapsed since the publication and this means less time to quote by the scientific community. 


\subsubsection{Source of Data}

There are several databases from which bibliometric data can be obtained, such as WoS or Scopus. However, in this work, it was decided to use the Google Scholar database, because it indexes not only IF journals but also other scientific publications, including books that do not have IF. Thus, data on the number of citations of publication data were obtained from Google Scholar citation. Included were publications that had LCA and/or LCM in the title or keywords as well as full headings Life Cycle Analysis/Assessment as well as Life Cycle Management.

In several cases, a problem was found due to the lack of a given author's profile on the Google Scholar platform. At that case, other available sources were used.

There are several ways to determine the citation index, including SCI, JCR and SJR. The study decided to use only JCR citation indicators that were obtained from the webpages of the magazine. Annual indicators were used, although the use of so-called 5-year indicators was also taken into account; however, they are not favourable for recent publications.

\subsubsection{Calculation of InOrdinatio}

The modified equation InOrdinatio (2) was applied for calculation:

$$
\text { InOrdinatio }=10 * \mathrm{IF}+\text { alfa } *[10-(\text { ResearchYear }- \text { PublishYear })]+\mathrm{Ci}
$$

As previously justified, IF was multiplied by 10 to reflect the importance of this indicator.

\section{Results and Discussion}

Research is done on the base of analysis of research activities on LCA and LCM presented in details in "Bibliometric analysis of Polish LCA's scientist performance" [14]. For each leading author from a given centre, the most-read publications with at least ten citations were usually selected. In the tables presented in report [14], they were listed according to the decreasing number of citations, from the highest first. After the InO calculations, the five best publications for the centre were selected.

The results started to be presented in alphabetical order according to the name of the leading author in the given centre, with Janusz Adamczyk, as the first author considered.

In Table 1 [14] the results of InOrdinatio for authors from the University of Zielona Góra are presented. The authors began publishing in 2014, but their best publications were published in high IF journals and reach InOrdinatio above 100 with the best InOrdinatio of 147.5. The main areas of their interest are ecological 
Table 1 The results of InOrdinatio for authors from the University of Zielona Góra

\begin{tabular}{l|l|l|l|l|l|l}
\hline $\begin{array}{l}\text { Order } \\
\text { number }\end{array}$ & $\begin{array}{l}\text { Publication number } \\
\text { according to the list }\end{array}$ & IF & $\begin{array}{l}\text { Number of } \\
\text { citation }\end{array}$ & $\begin{array}{l}\text { Year of } \\
\text { publication }\end{array}$ & InOrdinatio & Ranking \\
\hline 1 & {$[58]$} & 8.050 & 37 & 2016 & $\mathbf{1 4 7 . 5}$ & 1 \\
\hline 2 & {$[12]$} & 3.324 & 28 & 2015 & 101.24 & 5 \\
\hline 3 & {$[2]$} & 5.901 & 26 & 2014 & 134.01 & 2 \\
\hline 4 & {$[9]$} & 3.844 & 19 & 2014 & 107.44 & 3 \\
\hline 5 & {$[10]$} & 5.715 & 15 & 2016 & 102.15 & 4 \\
\hline 6 & {$[11]$} & 5.715 & 14 & 2016 & 101.15 & 6 \\
\hline
\end{tabular}

Table 2 The results of InOrdinatio for authors from the Central Mining Institute

\begin{tabular}{l|l|l|l|l|l|l}
\hline $\begin{array}{l}\text { Order } \\
\text { number }\end{array}$ & $\begin{array}{l}\text { Publication number } \\
\text { according to the list }\end{array}$ & IF & $\begin{array}{l}\text { Number of } \\
\text { citation }\end{array}$ & $\begin{array}{l}\text { Year of } \\
\text { publication }\end{array}$ & InOrdinatio & Ranking \\
\hline 1 & {$[4]$} & 3.590 & 119 & 2013 & $\mathbf{2 1 4 . 9}$ & 1 \\
\hline 2 & {$[5]$} & 4.900 & 32 & 2016 & 111.0 & 2 \\
\hline 3 & {$[18]$} & 5.651 & 27 & 2017 & 103.51 & 4 \\
\hline 4 & {$[27]$} & 5.715 & 23 & 2016 & 110.15 & 3 \\
\hline 5 & {$[7]$} & 4.601 & 18 & 2016 & 94.01 & 5 \\
\hline 6 & {$[6]$} & 4.610 & 15 & 2017 & 81.10 & \\
\hline 7 & {$[6]$} & 3.173 & 15 & 2016 & 56.73 & \\
\hline
\end{tabular}

and economic aspects of reducing low emissions using the LCA technique and LCA application in the construction industry.

Wacław Adamczyk from Cracow University of Economics should be second. His publication achievements can be found in the literature list [3]; however, the lack of his Google Scholar profile makes impossible the analysis of Methodi Ordinatio. However, it should be mentioned that Adamczyk and his team is one of the precursors in promoting life cycle thinking in relation to products. Noteworthy is also the organization of several editions of the Ecology of Products conferences, which resulted in important monographs [3]. The use of the LCA method in the decision-making processes of production companies and in their product policy is currently the main scope of activity of this research group.

In Table 2 [14] the best publications of the group whose leader is Burchard-Korol are presented. The group leader while working at the Central Mining Institute has carried out extensive work on the application of life cycle assessment and ecoefficiency in mining and quarrying sectors. From 2018 (at the Silesian University of Technology, Faculty of Transport), she has been examining the importance of assessing the environmental life cycle of transport. Noteworthy is the publication [4], which already has 119 citations, which gives rather high InOrdinatio equal 214,9.

Similar research issues were carried out by Czaplicka-Kolarz (currently she works at the Silesian University of Technology, Faculty of Organization and Development). Her papers were summarized in Table 3 [14] with the best InOrdinatio equal 111.0. 
Table 3 The results of InOrdinatio for Czaplicka-Kolarz from the Central Mining Institute

\begin{tabular}{l|l|l|l|l|l|l}
\hline $\begin{array}{l}\text { Order } \\
\text { number }\end{array}$ & $\begin{array}{l}\text { Publication number } \\
\text { according to the list }\end{array}$ & IF & $\begin{array}{l}\text { Number of } \\
\text { citation }\end{array}$ & $\begin{array}{l}\text { Year of } \\
\text { publication }\end{array}$ & InOrdinatio & Ranking \\
\hline 1 & {$[5]$} & 4.900 & 32 & 2016 & $\mathbf{1 1 1 . 0}$ & 1 \\
\hline 2 & {$[18]$} & 5.651 & 27 & 2017 & 103.51 & 2 \\
\hline 3 & {$[7]$} & 4.601 & 18 & 2016 & 94.01 & 3 \\
\hline 4 & {$[6]$} & 3.173 & 15 & 2016 & 56.73 & 4 \\
\hline
\end{tabular}

Table 4 The results of InOrdinatio for Foltynowicz group (from Poznan University of Economics and Business)

\begin{tabular}{l|l|l|l|l|l|l}
\hline $\begin{array}{l}\text { Order } \\
\text { number }\end{array}$ & $\begin{array}{l}\text { Publication number } \\
\text { according to the list }\end{array}$ & IF & $\begin{array}{l}\text { Number of } \\
\text { citation }\end{array}$ & $\begin{array}{l}\text { Year of } \\
\text { publication }\end{array}$ & InOrdinatio & Ranking \\
\hline 1 & {$[43]$} & 1.6 & 39 & 2004 & $\mathbf{1 3 0 . 0}$ & 1 \\
\hline 2 & {$[44]$} & 1.8 & 19 & 2008 & 92.0 & 4 \\
\hline 3 & {$[40]$} & 0.366 & 14 & 2004 & 92.66 & 3 \\
\hline 4 & {$[39]$} & 1.6 & 10 & 2004 & 101.0 & 2 \\
\hline
\end{tabular}

Table 5 The results of InOrdinatio for research group from Poznan University of Technology

\begin{tabular}{l|l|l|l|l|l|l}
\hline $\begin{array}{l}\text { Order } \\
\text { number }\end{array}$ & $\begin{array}{l}\text { Publication number } \\
\text { according to the list }\end{array}$ & IF & $\begin{array}{l}\text { Number of } \\
\text { citation }\end{array}$ & $\begin{array}{l}\text { Year of } \\
\text { publication }\end{array}$ & InOrdinatio & Ranking \\
\hline 1 & {$[57]$} & 1.039 & 62 & 2000 & 157.39 & 3 \\
\hline 2 & {$[41]$} & 3.148 & 50 & 2010 & $\mathbf{1 7 1 . 4 8}$ & 1 \\
\hline 3 & {$[35]$} & 3.148 & 32 & 2010 & 163.24 & 2 \\
\hline 4 & {$[65]$} & 3.988 & 29 & 2014 & 118.88 & 4 \\
\hline 5 & {$[45]$} & 3.089 & 26 & 2013 & 116.89 & $5^{*}$ \\
\hline 6 & {$[17]$} & 3.173 & 19 & 2016 & 80.73 & \\
\hline 7 & {$[32]$} & 2.362 & 13 & 2011 & 116.82 & $5^{*}$ \\
\hline 8 & {$[59]$} & 3.988 & 12 & 2014 & 101.88 & \\
\hline 9 & {$[34]$} & 3.988 & 8 & 2014 & 97.88 & \\
\hline
\end{tabular}

*Same rank because of very small difference

Table 4 [14] presents the achievements of Foltynowicz group from Poznan University of Economics and Business, which was the third one who started LCA in Poland. The initial research was devoted to comparative LCA analysis of industrial objects followed by the expansive works of Lewandowska. The highest rate of InOrdinatio (130.0) is attributed to exhibit paper published in 2004 [43]. Currently, the group publishes works in the field of renewable energy (see [51, 52]).

Table 5 [14] presents the achievements of the research group from PUT Poznan (Kłos, Kasprzak, Kurczewski, et al.). The authors began publishing before year 2000 [23-25]. Their best publications reach InOrdinatio above 100 with the best of 171.48. The main areas of their interest are very broad, among other life cycle thinking in small and medium enterprises and an environmental life cycle assessment of machines and devices. 
Table 6 The results of InOrdinatio for Korol

\begin{tabular}{l|l|l|l|l|l|l}
\hline $\begin{array}{l}\text { Order } \\
\text { number }\end{array}$ & $\begin{array}{l}\text { Publication number } \\
\text { according to the list }\end{array}$ & IF & $\begin{array}{l}\text { Number of } \\
\text { citation }\end{array}$ & $\begin{array}{l}\text { Year of } \\
\text { publication }\end{array}$ & InOrdinatio & Ranking \\
\hline 1 & {$[27]$} & 5.715 & 23 & 2016 & $\mathbf{1 1 0 . 1 5}$ & 1 \\
\hline 2 & {$[6]$} & 3.173 & 15 & 2016 & 56.73 & 2 \\
\hline
\end{tabular}

Table 7 The results of InOrdinatio for research group from Mineral and Energy Economy Research Institute of the Polish Academy of Sciences in Cracow

\begin{tabular}{l|l|l|l|l|l|l}
\hline $\begin{array}{l}\text { Order } \\
\text { number }\end{array}$ & $\begin{array}{l}\text { Publication number } \\
\text { according to the list }\end{array}$ & IF & $\begin{array}{l}\text { Number of } \\
\text { citation }\end{array}$ & $\begin{array}{l}\text { Year of } \\
\text { publication }\end{array}$ & InOrdinatio & Ranking \\
\hline 1 & {$[33]$} & 0.79 & 30 & 2015 & 77.9 & \\
\hline 2 & {$[45]$} & 3.089 & 26 & 2013 & $\mathbf{1 1 6 . 8 9}$ & 1 \\
\hline 3 & {$[21]$} & 4.732 & 24 & 2017 & 91.32 & \\
\hline 4 & {$[37]$} & 3.173 & 24 & 2016 & 85.73 & \\
\hline 5 & {$[31]$} & 3.331 & 23 & 2016 & 86.31 & \\
\hline 6 & {$[28]$} & 0.25 & 23 & 2004 & 100.5 & 3 \\
\hline 7 & {$[20]$} & 0.153 & 21 & 2005 & 92.5 & 5 \\
\hline 8 & {$[30]$} & 2.6 & 20 & 2009 & 96.0 & 4 \\
\hline 9 & {$[29]$} & 1.0 & 19 & 2007 & 89.0 & \\
\hline 10 & {$[32]$} & 2362 & 13 & 2011 & 116.62 & 2 \\
\hline
\end{tabular}

The achievements of Korol from the Central Mining Institute who is dealing with the evaluation of environmental footprints of biopolymers are shown in Table 6 [14].

Next, the achievements of two groups, whose leaders are strong women in LCA's science, will be presented. Table 7 [14] presents the achievements of the group whose leader is Kulczycka (Mineral and Energy Economy Research Institute of the Polish Academy of Sciences in Cracow). The issues of many works are very broad, but as befits the institute in which they work, it mainly concerns LCA issues in the field of the mineral and energy industry. The tabular summary (Table 7 [14]) shows how IF affects the InOrdinatio index. Although the largest is equal to 116.89 , most publications have high citation.

Table 8 [14], which presents the achievements of the group led by Lewandowska from Poznan University of Economics and Business, contains more articles than in other cases. The reason is not only the number of publications but also the fact that they are the result of extensive cooperation with other research groups. Twelve of these works have InOrdinatio above 100. The largest InOrdinatio reach values in the range 150-170. The issues of these works include both practical and methodological aspects in the field of LCA.

The next two cases present the results of groups that publish a lot, but either in Polish language or in magazines with small IF, which affects not very high InOrdinatio. Table 9 [14] presents the achievements of the Nitkiewicz team. Nitkiewicz comes from the Kraków group of Adamczyk and currently forms a group in Częstochowa (Center of Life Cycle Modeling). Research work of this group is directly related to LCA and its applicability. Group members have 
Table 8 The results of InOrdinatio for research group from Poznan University of Economics and Business

\begin{tabular}{l|l|l|l|l|l|l}
\hline $\begin{array}{l}\text { Order } \\
\text { number }\end{array}$ & $\begin{array}{l}\text { Publication number } \\
\text { according to the list }\end{array}$ & IF & $\begin{array}{l}\text { Number of } \\
\text { citation }\end{array}$ & $\begin{array}{l}\text { Year of } \\
\text { publication }\end{array}$ & InOrdinatio & Ranking \\
\hline 1 & {$[55]$} & 2.296 & 60 & 2014 & 132.96 & 4 \\
\hline 2 & {$[38]$} & 2.362 & 53 & 2011 & 156.62 & 3 \\
\hline 3 & {$[41]$} & 3.148 & 50 & 2010 & $\mathbf{1 7 1 . 4 8}$ & $\mathbf{1}$ \\
\hline 4 & {$[56]$} & 3.341 & 40 & 2014 & 123.41 & \\
\hline 5 & {$[43]$} & 1.6 & 39 & 2004 & 130.0 & \\
\hline 6 & {$[42]$} & 2.296 & 35 & 2014 & 106.96 & \\
\hline 7 & {$[46]$} & 2.465 & 35 & 2013 & 119.65 & 5 \\
\hline 8 & {$[35]$} & 3.148 & 32 & 2010 & 163.24 & 2 \\
\hline 9 & {$[47]$} & 3.324 & 31 & 2015 & 104.24 & \\
\hline 10 & {$[65]$} & 2.296 & 29 & 2014 & 101.96 & \\
\hline 11 & {$[45]$} & 3.089 & 26 & 2013 & 116.89 & \\
\hline 12 & {$[37]$} & 3.173 & 24 & 2016 & 85.73 & \\
\hline 13 & {$[17]$} & 3.173 & 19 & 2016 & 80.73 & \\
\hline 14 & {$[44]$} & 1.8 & 19 & 2008 & 92.0 & \\
\hline 15 & {$[40]$} & 0.366 & 14 & 2004 & 92.66 & \\
\hline & {$[32]$} & 2.362 & 13 & 2011 & 116.62 & \\
\hline
\end{tabular}

Table 9 The results of InOrdinatio for research group from the Faculty of Management at Częstochowa University of Technology

\begin{tabular}{l|l|l|l|l|l|l}
\hline $\begin{array}{l}\text { Order } \\
\text { number }\end{array}$ & $\begin{array}{l}\text { Publication number } \\
\text { according to the list }\end{array}$ & IF & $\begin{array}{l}\text { Number of } \\
\text { citation }\end{array}$ & $\begin{array}{l}\text { Year of } \\
\text { publication }\end{array}$ & InOrdinatio & Ranking \\
\hline 1 & {$[61]$} & 1.08 & 10 & 2015 & $\mathbf{6 0 . 8}$ & 1 \\
\hline 2 & {$[62]$} & 0 & 7 & 2014 & 57 & 2 \\
\hline 3 & {$[53]$} & 1.334 & 1 & 2017 & 43.34 & 3 \\
\hline
\end{tabular}

Table 10 The results of InOrdinatio for research group from UTP University of Science and Technology in Bydgoszcz

\begin{tabular}{l|l|l|l|l|l|l}
\hline $\begin{array}{l}\text { Order } \\
\text { number }\end{array}$ & $\begin{array}{l}\text { Publication number } \\
\text { according to the list }\end{array}$ & IF & $\begin{array}{l}\text { Number of } \\
\text { citation }\end{array}$ & $\begin{array}{l}\text { Year of } \\
\text { publication }\end{array}$ & InOrdinatio & Ranking \\
\hline 1 & {$[63]$} & 0.763 & 11 & 2017 & $\mathbf{3 8 . 6 3}$ & 1 \\
\hline 2 & {$[13]$} & 1.21 & 9 & 2018 & 31.1 & 2 \\
\hline 3 & {$[64]$} & 1.214 & 4 & 2018 & 26.14 & 3 \\
\hline
\end{tabular}

published about 30 scientific works, however, mainly in Polish publishing houses, which results that only three of them have citations. This is reflected in the low InOrdinatio values.

The situation is similar in the case of Tomporowski research group from UTP Bydgoszcz. Table 10 [14] presents selected achievements of this research group, which are cited publications from indexed periodicals. Although these publications 
have been published in recent years, they already have citations. Other numerous publications in non-indexed periodicals affect InOrdinatio. The subject of this research is very current and focuses on various aspects of the LCA of an offshore wind farm.

In addition to the above research groups, LCA/LCM analyses are carried out in several other centres, as evidenced by the number of licenses purchased for SimaPro or GaBi computing programs, like at ZUT (West Pomeranian University of Technology, Szczecin [8]), Łódź University [48, 49] and COBRO Institute [36, 66, 67].

\section{Reassuming and Conclusions}

The bibliometric analysis of Polish LCA's scientists' performance has been performed. Based on the review of discipline-related journals and the information collected, InOrdinatio was determined using the Methodi Ordinatio. The year of publication and the number of citations of the publication were taken into account, as well as the IF of the magazine in which the article was published. On this basis, InOrdinatio was determined, and the best five publications from a given centre were

Table 11 Ranking of the best papers from Polish LCA research groups

\begin{tabular}{l|l|l|l|l|l|l|l}
\hline $\begin{array}{l}\text { Ranking } \\
\text { number }\end{array}$ & $\begin{array}{l}\text { Publication } \\
\text { number }\end{array}$ & IF & $\begin{array}{l}\text { Number } \\
\text { of } \\
\text { citation }\end{array}$ & $\begin{array}{l}\text { Year of } \\
\text { publication }\end{array}$ & InOrdinatio & $\begin{array}{l}\text { InOrdinatio } \\
5 s\end{array}$ & Group \\
\hline 1 & {$[4]$} & 3.590 & 119 & 2013 & 214.90 & 523.42 & $\begin{array}{l}\text { Burchard- } \\
\text { Korol group }\end{array}$ \\
\hline $2 \mathrm{a}$ & {$[41]$} & 3.148 & 50 & 2010 & 171.48 & 743.95 & $\begin{array}{l}\text { Lewandowska } \\
\text { PUEB group }\end{array}$ \\
\hline $2 \mathrm{~b}$ & {$[41]$} & 3.148 & 50 & 2010 & 171.48 & 727.88 & $\begin{array}{l}\text { PUT Poznan } \\
\text { group Kłos }\end{array}$ \\
\hline 3 & {$[58]$} & 8.050 & 37 & 2016 & 147.50 & 592.34 & $\begin{array}{l}\text { Univ. of } \\
\text { Z. Góra group }\end{array}$ \\
\hline 4 & {$[43]$} & 1.6 & 39 & 2004 & 130.00 & 415.66 & $\begin{array}{l}\text { Foltynowicz } \\
\text { PUEB group }\end{array}$ \\
\hline 5 & {$[45]$} & 3.089 & 26 & 2013 & 116.89 & 522.51 & $\begin{array}{l}\text { Kulczycka } \\
\text { group }\end{array}$ \\
\hline 6 & {$[5]$} & 4.900 & 32 & 2016 & 111.00 & 478.73 & $\begin{array}{l}\text { Czaplicka- } \\
\text { Kolarz et al. }\end{array}$ \\
\hline 7 & {$[27]$} & 5.715 & 23 & 2016 & 110.15 & 166.88 & Korol et al. \\
\hline 8 & {$[61]$} & 1.08 & 10 & 2015 & 60.80 & 161.14 & $\begin{array}{l}\text { Częstochowa } \\
\text { LCM Center }\end{array}$ \\
\hline 9 & {$[63]$} & 0.763 & 11 & 2017 & 38.63 & 95.87 & $\begin{array}{l}\text { UTP } \\
\text { Bydgoszcz } \\
\text { group }\end{array}$ \\
\hline
\end{tabular}

Source: own research

aPublication number according to the References section 
selected. This allowed the ranking of the best publications of Polish authors to be made. Table 11 presents a summary of the best works from individual research groups.

The largest InOrdinatio characterized a work by Burchard-Korol et al. [4], which has been cited 119 times. Second place comes joint publication of authors from PUEB and PUT. The third place is for the group from the University of Zielona Góra. The largest InOrdinatio does not always seem to reflect the actual position of a given group, especially when other publications have smaller InOrdinatio. That is why InOrdinatio was summarized for the five best publications from a given group, resulting in InOrdinatio 5s. It turned out that the leader is Lewandowska group, which accumulated almost 744 InOrdinatio 5s points. The second place with the result of 728 points of InOrdinatio 5s was taken by the team led by Kłos. The third position is occupied by the group from the University of Zielona Góra with 592 InOrdinatio 5s and next (523 InOrdinatio 5s) places are for the Burchard group and Kulczycka group. InOrdinatio was determined using JRC indexes. Perhaps the use of other parametric indexes would affect the ranking results, which will be checked in the future.

It is worth noting that the cooperation of the PUT, PUEB and Polish Academy of Sciences in Cracow groups brings very good scientific and bibliometric results. It is also worth mentioning that Polish scientists are establishing international cooperation, which also brings effects in the form of indexed publications.

One should also mention the numerous monographs on the subject of LCA/LCM by Polish authors, which, however, appeared in Polish. Polish scientists are also coauthors of numerous chapters in monographs. Over 20 doctorates in this field were already defended, and several researchers also obtained postdoctoral degrees. This aspect, however, goes beyond the accepted scope of this study.

\section{References}

1. Adamczyk, W. (1999). Ecobalance - A tool for environmental evaluation of products and manufacturing processes, proceedings of the 12th IGWT symposium (pp. 670-675). Poznan University of Economic.

2. Adamczyk, J., \& Dzikuć, M. (2014). The analysis of suppositions included in the polish energetic policy using the LCA technique-Poland case study. Renewable and Sustainable Energy Reviews, 39, 42-50.

3. bazybg.uek.krakow.pl (https://bazybg.uek.krakow.pl/dorobek/welcome/bibliografia/66/0/0/0)

4. Burchart-Korol, D. (2013). Life cycle assessment of steel production in Poland: A case study. Journal of Cleaner Production, 54, 235-243.

5. Burchart-Korol, D., Fugiel, A., Czaplicka-Kolarz, K., \& Turek, M. (2016). Model of environmental life cycle assessment for coal mining operations. Science of the Total Environment, $562,61-72$.

6. Burchart-Korol, D., Korol, J., \& Czaplicka-Kolarz, K. (2016). Life cycle assessment of heat production from underground coal gasification. The International Journal of Life Cycle Assessment, 21(10), 1391-1403.

7. Burchart-Korol, D., Krawczyk, P., Czaplicka-Kolarz, K., \& Smoliński, A. (2016). Ecoefficiency of underground coal gasification (UCG) for electricity production. Fuel, 173, 239-246. 
8. Danilecki, K., Mrozik, M., \& Smurawski, P. (2017). Changes in the environmental profile of a popular passenger car over the last 30 years - Results of a simplified LCA study. Journal of Cleaner Production, 141, 208-218.

9. Dylewski, R., \& Adamczyk, J. (2014). The comparison of thermal insulation types of plaster with cement plaster. Journal of Cleaner Production, 83, 256-262.

10. Dylewski, R., \& Adamczyk, J. (2016). Study on ecological cost-effectiveness for the thermal insulation of building external vertical walls in Poland. Journal of Cleaner Production, 133, 467-478.

11. Dylewski, R., \& Adamczyk, J. (2016). The environmental impacts of thermal insulation of buildings including the categories of damage: A polish case study. Journal of Cleaner Production, 137, 878-887.

12. Dzikuć, M., \& Adamczyk, J. (2015). The ecological and economic aspects of a low emission limitation: A case study for Poland. The International Journal of Life Cycle Assessment, 20(2), 217-225.

13. Flizikowski, J., Piasecka, I., Kruszelnicka, W., Tomporowski, A., \& Mroziński, A. (2018). Destruction assessment of wind power plastics blade. Polimery, 63, 9.

14. Foltynowicz, Z., \& Kłos, Z. (2019). https://www.researchgate.net/ publication/338018588_Bibliometric_analysis_of_Polish_LCA's_scientist_performance

15. Foltynowicz, Z., \& Lewandowska, A. (2005). Life cycle assessment in Poland - General review. Forum Ware International, 6(1), 7-10.

16. Foltynowicz, Z., Kłos, Z., Kurczewski, P., \& Lewandowska, A. (2006). Environmental designing of technical objects as a basis for life cycle management (LCM) - Case Study for Poland, 2nd international conference on quantifies eco-efficiency analysis for sustainability, 28-30 June 2006 Egmond aan Zee, Netherlands.

17. Fuc, P., Kurczewski, P., Lewandowska, A., Nowak, E., Selech, J., \& Ziolkowski, A. (2016). An environmental life cycle assessment of forklift operation: A well-to-wheel analysis. The International Journal of Life Cycle Assessment, 21(10), 1438-1451.

18. Fugiel, A., Burchart-Korol, D., Czaplicka-Kolarz, K., \& Smolińskic, A. (2017). Environmental impact and damage categories caused by air pollution emissions from mining and quarrying sectors of European countries. Journal of Cleaner Production, 143, 159-168.

19. Garfield, E. (2006). The history and meaning of the journal impact factor. The Journal of the American Medical Association, 295(1), 90-94.

20. Góralczyk, M., \& Kulczycka, J. (2005). LCC application in the polish mining industry. Management of Environmental Quality: An International Journal, 16(2), 119-112.

21. Gorazda, K., Tarko, B., Wzorek, Z., Kominko, H., Nowak, A. K., \& Kulczycka, J. (2017). Fertilisers production from ashes after sewage sludge combustion-A strategy towards sustainable development. Environmental Research, 154, 171-180.

22. Guinée, J. (2016). Chapter 3: Life cycle sustainability assessment: What is it and what are its challenges? In R. Clift \& A. Druckman (Eds.), Taking stock of industrial ecology. Springer Open. https://doi.org/10.1007/978-3-319-20571-7_3

23. Kłos Z. (1986). Rozważania o celowości wyznaczania środowiskowego kosztu istnienia maszyn i urządzeń. Zeszyty Naukowe Politechniki Poznańskiej, seria: Maszyny Robocze i Pojazdy, 1986, no. 26, p. 75-85 (in Polish).

24. Kłos, Z. (1990). Sozologiczność obiektów technicznych. Wydawnictwo Politechniki Poznańskiej.

25. Kłos, Z. (1999). LCA in Poland: Background and state-of-art. The International Journal of Life Cycle Assessment, 7(5), 249-250.

26. Kłos, Z., \& Kurczewski, P. (2009). LCA in Poznań and Poland. Research teams and their achievements. Scientific Problems of Machines Operation and Maintenance, 2(158), 85-99. http://t.tribologia.org/plik/spm/spmom-09v44n2_p-085.pdf

27. Korol, J., Burchart-Korol, D., \& Pichlak, M. (2016). Expansion of environmental impact assessment for eco-efficiency evaluation of biocomposites for industrial application. Journal of Cleaner Production, 113, 144-152. 
28. Kowalski, Z., \& Kulczycka, J. (2004). Cleaner production as a basic element for the sustainable development strategy. Polish Journal of Chemical Technology, 6(4), 35-40.

29. Kowalski, Z., Kulczycka, J., \& Wzorek, Z. (2007). Life cycle assessment of different variants of sodium chromate production, Poland. Journal of Cleaner Production, 15(1), 28-37.

30. Kulczycka, J. (2009). Life cycle thinking in polish official documents and research. The International Journal of Life Cycle Assessment, 14(5), 375-378.

31. Kulczycka, J., \& Smol, M. (2016). Environmentally friendly pathways for the evaluation of investment projects using life cycle assessment (LCA) and life cycle cost analysis (LCCA). Clean Technologies and Environmental Policy, 18(3), 829-842.

32. Kulczycka, J., Kasprzak, J., Kurczewski, P., Lewandowska, A., Lewicki, R., Witczak, A., \& Witczak, J. (2011). The polish Centre for Life Cycle Assessment-The Centre for life cycle assessment in Poland. The International Journal of Life Cycle Assessment, 5, 442-444.

33. Kulczycka, J., Lelek, L., Lewandowska, A., \& Zarebska, J. (2015). Life cycle assessment of municipal solid waste management--comparison of results using different LCA models. Polish Journal of Environmental Studies, 24(1).

34. Kurczewski, P. (2014). Life cycle thinking in small and medium enterprises: The results of research on the implementation of life cycle tools in polish SMEs-Part 1: Background and framework. The International Journal of Life Cycle Assessment, 19(3), 593-600.

35. Kurczewski, P., \& Lewandowska, A. (2010). ISO 14062 in theory and practice-Ecodesign procedure. Part 2: Practical application. The International Journal of Life Cycle Assessment, 15(8), 777-784.

36. Kuzincow, J., \& Ganczewski, G. (2015). Life cycle management as a crucial aspect of corporate social responsibility. Research Papers of the Wroclaw University of Economics / Prace Naukowe Uniwersytetu Ekonomicznego we Wroclawiu, 387, 91-108.

37. Lelek, L., Kulczycka, J., Lewandowska, A., \& Zarebska, J. (2016). Life cycle assessment of energy generation in Poland. The International Journal of Life Cycle Assessment, 21(1), 1-14.

38. Lewandowska, A. (2011). Environmental life cycle assessment as a tool for identification and assessment of environmental aspects in environmental management systems (EMS) part 1: Methodology. The International Journal of Life Cycle Assessment, 16(2), 178-186.

39. Lewandowska, A., \& Foltynowicz, Z. (2004). Comparative LCA analysis of industrial objects part II: Case study for chosen industrial pumps. The International Journal of Life Cycle Assessment, 9(3), 180-186.

40. Lewandowska, A., \& Foltynowicz, Z. (2004). New direction of development in environmental life cycle assessment. The Polish Journal of Environmental Studies, 13(5), 463-466.

41. Lewandowska, A., \& Kurczewski, P. (2010). ISO 14062 in theory and practice-Ecodesign procedure. Part 1: Structure and theory. The International Journal of Life Cycle Assessment, 15(8), 769-776.

42. Lewandowska, A., \& Matuszak-Flejszman, A. (2014). Eco-design as a normative element of environmental management systems-The context of the revised ISO 14001: 2015. The International Journal of Life Cycle Assessment, 19(11), 1794-1798.

43. Lewandowska, A., Foltynowicz, Z., \& Podleśny, A. (2004). Comparative LCA analysis of industrial objects part I: LCA data quality assurance - Sensitivity analysis and pedigree matrix. The International Journal of Life Cycle Assessment, 9(2), 86-89.

44. Lewandowska, A., Wawrzynkiewicz, Z., Noskowiak, A., \& Foltynowicz, Z. (2008). Adaptation of ecoinvent database to polish conditions. The International Journal of Life Cycle Assessment, 13(4), 319.

45. Lewandowska, A., Kurczewski, P., Kulczycka, J., Joachimiak, K., Matuszak-Flejszman, A., Baumann, H., \& Ciroth, A. (2013). LCA as an element in environmental management systems-Comparison of conditions in selected organisations in Poland, Sweden and Germany. The International Journal of Life Cycle Assessment, 18(2), 472-480.

46. Lewandowska, A., Noskowiak, A., \& Pajchrowski, G. (2013). Comparative life cycle assessment of passive and traditional residential buildings' use with a special focus on energy-related aspects. Energy and Buildings, 67, 635-646. 
47. Lewandowska, A., Noskowiak, A., Pajchrowski, G., \& Zarebska, J. (2015). Between full LCA and energy certification methodology-A comparison of six methodological variants of buildings environmental assessment. The International Journal of Life Cycle Assessment, 20(1), 9-22.

48. Marcinkowski, A. (2018). Environmental efficiency of industrial Symbiosis - LCA case study for gypsum exchange. Multidisciplinary Aspects of Production Engineering - MAPE, 1(1), 793-800.

49. Marcinkowski, A., \& Zych, K. (2017). Environmental performance of kettle production: Product life cycle assessment. Management Systems in Production Engineering, 25(4), 255-261.

50. McKiernan, E. C., Schimanski, L. A., Muñoz, N. C., Matthias, L., Niles, M. T., \& Alperin, J. P. (2019). Use of the journal impact factor in academic review, promotion, and tenure evaluations. eLife, 8, e47338. https://doi.org/10.7554/eLife.47338

51. Muradin, M., \& Foltynowicz, Z. (2018). Logistic aspects of the ecological impact indicators of an agricultural biogas plant. LogForum, 14(4), 535-547. https://doi.org/10.17270/J. LOG.2018.306

52. Muradin, M., Joachimiak-Lechman, K., \& Foltynowicz, Z. (2018). Evaluation of ecoefficiency of two alternative agricultural biogas plants. Applied Sciences, 8, 2083. https://doi. org/10.3390/app8112083

53. Nitkiewicz, T., \& Starostka-Patyk, M. (2017). Contribution of returned products handling scenarios to life cycle impacts--research case of washing machine. Environmental Engineering \& Management Journal (EEMJ), 16(4), 1.

54. Pagani, R. N., Kovaleski, J. L., \& Resende, L. M. (2015). Methodi Ordinatio: A proposed methodology to select and rank relevant scientific papers encompassing the impact factor, number of citation, and year of publication. Scientometrics, 105, 2109-2135. https://doi. org/10.1007/s11192-015-1744-x

55. Pajchrowski, G., Noskowiak, A., Lewandowska, A., \& Strykowski, W. (2014). Wood as a building material in the light of environmental assessment of full life cycle of four buildings. Construction and Building Materials, 52, 428-436.

56. Pajchrowski, G., Noskowiak, A., Lewandowska, A., \& Strykowski, W. (2014). Materials composition or energy characteristic-What is more important in environmental life cycle of buildings? Building and Environment, 72, 15-27.

57. Pesonen, H. L., Ekvall, T., Fleischer, G., et al. (2000). Framework for scenario development in LCA. The International Journal of Life Cycle Assessment, 5, 21. https://doi.org/10.1007/ BF02978555

58. Piwowar, A., Dzikuć, M., \& Adamczyk, J. (2016). Agricultural biogas plants in Polandselected technological, market and environmental aspects. Renewable and Sustainable Energy Reviews, 58, 69-74.

59. Selech, J., Joachimiak-Lechman, K., Klos, Z., Kulczycka, J., \& Kurczewski, P. (2014). Life cycle thinking in small and medium enterprises: The results of research on the implementation of life cycle tools in polish SMEs-Part 3: LCC-related aspects. The International Journal of Life Cycle Assessment, 19(5), 1119-1128.

60. Śliwińska, A., Burchart-Korol, D., \& Smoliński, A. (2017). Environmental life cycle assessment of methanol and electricity co-production system based on coal gasification technology. Science of the Total Environment, 574, 1571-1579.

61. Starostka-Patyk, M. (2015). New products design decision making support by SimaPro software on the base of defective products management. Procedia Computer Science, 65, 1066-1074.

62. Starostka-Patyk, M., \& Nitkiewicz, T. (2014). LCA approach to management of defective products in reverse logistics channel, 2014 International conference on advanced logistics and transport. https://scholar.google.pl/citations?user=xZJ3Yx8AAAAJ\&hl=pl 
63. Tomporowski, A., Flizikowski, J., Opielak, M., Kasner, R., \& Kruszelnicka, W. (2017). Assessment of energy use and elimination of $\mathrm{CO} 2$ emissions in the life cycle of an offshore wind power plant farm. Polish Maritime Research, 24(4), 93-101.

64. Tomporowski, A., Piasecka, I., Flizikowski, J., Kasner, R., \& Kruszelnicka, W. (2018). Comparison analysis of blade life cycles of land-based and offshore wind power plants. Polish Maritime Research, 25(s1), 225-233.

65. Witczak, J., Kasprzak, J., Klos, Z., Kurczewski, P., Lewandowska, A., \& Lewicki, R. (2014). Life cycle thinking in small and medium enterprises - The results of research on the implementation of life cycle tools in polish SMEs part 2: LCA related aspects. The International Journal of Life Cycle Assessment, 19, 891-900.

66. Żakowska, H. (2004). Wytyczne dotyczące wykonania analizy cyklu życia (LCA) opakowań i ograniczenia tej metody. Guidelines for the performance of the Life Cycle Analysis (LCA) of packages and limitations in this method. Opakowanie, 11, 20-24.

67. Żakowska, H. (2014). Metoda LCA w logistyce odzysku odpadów opakowaniowych/LCA method in the logistics of packaging waste recovery. Logistyka Odzysku, 3(12), 22-24.

Open Access This chapter is licensed under the terms of the Creative Commons Attribution 4.0 International License (http://creativecommons.org/licenses/by/4.0/), which permits use, sharing, adaptation, distribution and reproduction in any medium or format, as long as you give appropriate credit to the original author(s) and the source, provide a link to the Creative Commons license and indicate if changes were made.

The images or other third party material in this chapter are included in the chapter's Creative Commons license, unless indicated otherwise in a credit line to the material. If material is not included in the chapter's Creative Commons license and your intended use is not permitted by statutory regulation or exceeds the permitted use, you will need to obtain permission directly from the copyright holder.

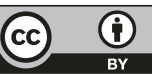

